\title{
Impact of the COVID-19 Pandemic on Audit Quality: Lessons and Opportunities
}

\author{
Saddam A. Hazaea ${ }^{1} \odot$, Mosab I. Tabash ${ }^{2 *}{ }^{\circ}$, Abdul Aziz Abdul Rahman ${ }^{3}{ }^{\circ}$, \\ Saleh F. A. Khatib ${ }^{4} \odot$, Jinyu Zhu ${ }^{1}$, H Gin Chong ${ }^{5}$ \\ ${ }^{1}$ School of Accounting, Yunnan University of Finance and Economics, Kunming 650221, China. \\ ${ }^{2}$ Al Ain University, Al Ain, United Arab Emirates. \\ ${ }^{3}$ College of Business Administration, Kingdom University, Riffa, Bahrain. \\ ${ }^{4}$ Department of Management, Azman Hashim International Business School, Universiti Teknologi Malaysia, Johor Baru 81310, Malaysia. \\ ${ }^{5}$ Prairie View A\&M University, United States.
}

\begin{abstract}
This study aims to identify the impact of COVID-19 on audit quality based on the investigation of three auditing aspects, namely: audit fees, audit procedures, and auditors' salaries in Saudi Arabia and Yemen. For data collection, fifty-five (55) questionnaires were distributed to internal auditors, external auditors, managers of audit offices, and financial managers. Eleven managers of audit offices and auditors were interviewed. A descriptive, regression analysis, and T-test were used. The study results reveal that the audit quality has been significantly affected due to the devastating effect of COVID-19 on audit fees, audit procedures, and audit staff salaries. In addition, the results show that Yemen is severely affected due to several factors, which include a lack of modern auditing systems. Also, private ownership of establishments and the absence of laws for determining audit fees negatively impacted the audit quality. Being the first of a practical kind, this study provides a significant contribution to the existing literature on the impact of COVID-19 on the quality of auditing. This would be useful for corporations, audit offices, auditors, and researchers. Moreover, this study can bridge the identified research gap on this topic and provide empirical evidence about the impact of COVID-19 on audit quality.
\end{abstract}

\section{Keywords:}

Audit Quality;

COVID-19;

Audit Fees;

Audit Procedure; Crisis.

\section{Article History:}

$\begin{array}{llll}\text { Received: } & 21 & \text { October } & 2021 \\ \text { Revised: } & 02 & \text { February } & 2022 \\ \text { Accepted: } & 10 & \text { February } & 2022 \\ \text { Published: } & 27 & \text { February } & 2022\end{array}$

\section{1- Introduction}

More recently, the world faced and is still facing major health, social, and economic challenges due to the outbreak of COVID-19, causing an international crisis that affected several aspects of the world economy. Due to the great role that the auditing profession plays in the world of business and finance, it inevitably keeps pace with the changes that occur in the environment in which it operates, as it is one of the vital components of the work environment. Previously, it was suggested that the perceived audit risk increased during the financial crisis of 2008 [1].

Initially, COVID-19 was only regarded as a health problem. However, its effects have surpassed expectations, and it poses health, economic, and social challenges. One of the early studies on corporate outcomes conducted by Khatib and Nour [2] found that the coronavirus has influenced all firms' aspects, including performance, governance attributes, and

* CONTACT: mosab.tabash@aau.ac.ae

DOI: http://dx.doi.org/10.28991/esj-2022-SPER-06

(C) 2022 by the authors. Licensee ESJ, Italy. This is an open access article under the terms and conditions of the Creative Commons Attribution (CC-BY) license (https://creativecommons.org/licenses/by/4.0/). 
audit committees. All institutions were affected, which led to an impact on all countries' economies because strict measures were taken by governments, including travel restrictions, social distancing policies, and the closure of institutions and centers of all kinds, in addition to orders to stay at home. Many studies revealed that the COVID-19 impact on the economic sector was harsh [3,4]. According to Castka et al. [5], the effects of COVID-19 were disastrous on economic well-being. The COVID-19 outbreak had significant financial and economic impacts in all countries [6]. The rapid spread of COVID-19 has led to the major economic turmoil that has resulted in investor distrust in the markets, which has caused financial pressures in all areas, affecting corporates' financial performance [7].

The COVID-19 led to a negative impact on the performance of the institutions, decreased liquidity, profits, and an impact on the companies' financial leverage [2], and a similar influence is expected on the auditing function. Castka et al. and Albitar et al. [5, 8] argued that the COVID-19 crisis might have a significant negative impact on both auditors and auditing quality. As a result of preventive measures, auditors may not be able to perform their work as required, which may reduce the quality of audit performance [9]. This inaccurate performance of audits may be a reason for not identifying ambiguous errors [10]. Failure to perform audits with high quality may expose institutions to a lack of investor confidence [11, 12]. During crisis times, it has been found that auditors did not realize major systemic risks [1]. We, therefore, argue that auditors might encounter some challenges during this health crisis, including manipulating profit numbers given this exceptional situation or challenges due to a lack of collecting all financial information about the operations that took place.

To cope with such challenges, some instructions have been introduced by the Financial Reporting Council related to audit practices during the Coronavirus time. This issuance contains instructions for auditors that must be applied when performing their work considering the social distancing measures [13]. This report specifies a set of functions and instructions that auditors must follow and investigate. It explains how the auditor can obtain sufficient and appropriate evidence to develop alternative procedures to confront any possibility including (i) evaluating the risks faced by the auditor: the auditor must evaluate the company's financial position and its prospects for continuity, and (ii) continuous and repeated evaluation of the work carried out by the auditor according to the changing situation resulting from the outbreak.

Despite the increased concern about the influence of COVID-19 on organizational facets, limited attention has been paid to the various auditing aspects. As a step in this direction, this study is a response to a call by Albitar et al. [8] for empirical research evaluating the impact of the COVID-19 health crisis on the auditing antecedents and outcomes since the existing studies are theoretical or review research. For example, Levy [9] has discussed the implication of auditing and financial reporting during the COVID-19 pandemic. It has been suggested that the perceptions of the effectiveness and efficiency have increased only for experience auditors during the pandemic [14]. Moreover, Albitar et al. [8] discussed the theoretical impact of the COVID-19 social distancing outbreak on audit quality. To the best of the authors' knowledge, this empirical study is the first to assess the impact of COVID-19 on several auditing aspects, namely audit fees, audit procedures, and auditors' salaries.

In addition, as a result of the impact of Covid-19 on all aspects of life, including business performance and its effects in the future, so far there are no practical studies attempting to identify the effects of Covid-19 on the audit performance. There have been no necessary recommendations to guide the stakeholders and concerned entities on how to avoid any damages that may be caused by future crises. Due to the absence of results based on practical analysis on this subject, we consider this study original. In this study, two methods were used for data collection; questionnaires (Appendix I), and interviews. The attempt is to combine elements of qualitative and quantitative approaches concurrently to ensure the required extensiveness and depth of understanding and validation. The data used were collected from two different markets, Saudi Arabia and Yemen. Moreover, the participants involved in this study are managers of audit offices, internal auditors, external auditors, and financial managers. We found that COVID-19 has a negative impact on audit fees, audit procedures, and auditing staff salaries. This is in line with other studies that suggested crisis reveals systemic risks that auditors did not realize in the non-crisis periods [1, 15] and therefore affect auditor's attributes. Zhang and Huang [15] confirmed that audit fees and firm risk would be seriously shocked by the crisis.

This study contributes to existing research by being the first empirical study to provide inferences on auditing aspects during the COVID-19 crisis. While few theoretical and conceptual studies. [8,9] discussed the influence of Coronavirus on auditor performance and outcomes, empirical studies on this area are absent. This study, therefore, adds to the literature by filling the gap in research about the influence of the current health crisis on auditing practices from two developing markets. The findings of the study would provide researchers and practitioners with a deeper understanding of auditing activities to employ in practice and future research endeavours in this underexplored area. In addition, it is expected that this study would contribute to emergency and crises management and their effects on the exercise of audit functions and clarify the methods that managers and stakeholders, as well as interested institutions, can follow and work on developing regulations and standards in line with work in light of crises. This study also provides a deeper understanding of the impact of public crises such as COVID-19 or private crises such as financial crises by providing some analyses of the various results on the exercise of audit functions. 


\section{2- Literature Review}

Expectations about the rapid spread and continuation of the epidemic indicate a high probability of bankruptcy of many companies and the collapse of some projects. In addition, repercussions resulting from the epidemic are expected to lead to the loss of many jobs $[5,16,17]$. As societies suffer from shrinking services, rationing of goods and many business organizations may not recover, especially small businesses, and for many companies, their financial situation can become highly complex. Internal audit can play a vital role in COVID-19 through three dimensions. The first dimension, checking the continuity of the institution's work, crisis management, and continuing for new crisis preparedness. It is noted that internal auditing has an essential role before the spread of the epidemic, which is to check business continuity and preparedness for any crisis and thus ensure the ability to manage the risks of the epidemic crisis when it occurs.

The second dimension is when an unexpected crisis occurs, such as the spread of COVID-19. In this case, the internal audit services, through reassessing the strategic audit plan, become mitigated which are roles and tasks that may affect the independence of internal auditing, such as assisting in some necessary and unconventional work, as well. Providing front-line services to support customer needs, participating in mapping external dependencies, identifying primary suppliers and service providers, and defining business continuity metrics. The third dimension is when the crisis is over. In this phase, there is a real opportunity for internal auditing to provide services that directly support recovery efforts, as consulting services can be provided on problems such as liquidity management, customer recovery, and searching for new markets that the crisis has produced. In addition, following the crisis effects and its aftermath and the extent to which the integrity elements are achieved.

The internal audit has been significantly affected by the COVID-19. The impact appears to vary depending on geographic location, industry, and government. Thus, acting during a crisis by repeatedly assessing risks is vital to reprioritize institutions during the times of crisis. By identifying and prioritizing risks arising from the pandemic, audit leaders can help executive leadership develop appropriate mitigation measures and strategies to ensure business objectives and sustainability. One of the main risks that the internal auditors' managers assess during this time is the impact on revenue, employee's safety and welfare, supply chain, cybersecurity, and ensuring that the collection and storage of evidence are appropriately controlled.

\section{2-1-Audit Fees}

The quality of audit reports might be affected by audit fees [18-20]. Dependng on the complexity of the service, whenever more fees are paid, the performance by auditing experts is expected to be better [21]. Institutions and auditors faced significant challenges because of the COVID-19 spread, as it affected all the characteristics of companies of all kinds, financial and non-financial, including the effect on performance, governance, liquidity, profits, as well as financial leverage [2]. According to Chen et al. [1], the unexpected economic conditions represent a significant challenge for companies and stakeholders, as changes affect liquidity, performance, and risk, which lead to higher audit fees. Given the risks, auditors may add additional fees to the approved fees [22].

During an unstable financial situation, audit fees are affected due to the increased risk [23]. According to Bell et al. [24] there is a direct relationship between the audit risk and the number of work hours that the auditors spend, which leads to a demand to raise audit fees. According to Rose [25] the audit fees are high when the level of risk is high. Considering the risks, companies may abandon and violate the rights of auditors, which significantly contributes to the companies' exposure to bankruptcy [1]. Unstable economic conditions may affect the increase in audit fees [26]. Some studies have proven that there is a positive relationship between audit fees and the financial crisis resulting from risks. Rose et al. [27] proved that there is a positive relationship between audit fees and the financial crisis. Other studies showed that there is a positive relationship between audit fees in Chinese companies and the financial crisis [15]. During the period of the crisis, auditors' effort and working hours will increase, leading to an increased risk of audit litigation [28].

Firms may request a reduction in audit fees from auditing firms through working hours and audit efforts to increase during a pandemic [1]. There is an impact of COVID-19 on audit fees, which contributes to reducing the quality of auditing [29]. As a result of stopping or decreasing financial operations, auditors may be exposed to pressure from the companies and institutions they work with or from clients to reduce audit fees during risk situations COVID- 19, and thus the decrease in audit fees may affect the quality of the audit [8]. The first hypothesis is:

H1. With other conditions residual the same, the COVID-19 epidemic has harmed the audit fees.

\section{2-2-Audit Procedures}

The audit procedures may be affected by COVID-19, the audit procedures being an essential part of the audit process. Among the negative consequences of the impact of COVID-19 on the quality of auditing are the procedures that led to the implementation of the work from home [29]. Analytical procedures are an essential part of an audit of financial 
statements [30]. Analytical procedures are one of the essential factors in auditing financial statements, and it is about auditors preparing and investigating multiple financial operations [31].

Among the indicators that are followed to determine whether auditors are performing their work efficiently is the extent of their compliance with the required audit procedures [32]. Audit quality assurance is related to the extent to which auditors follow audit procedures [33]. According to Wright and Ashton [34] three procedures contribute to improving the quality of the auditing (i) analytical review, which means comparing the current year balances with the previous year balances (ii) customer inquiry (matching balances), and (ii) expectations based on previous years' errors. Analytical auditing procedures are used in many tasks, including proper audit planning, survey work, audit evaluation, as well as preparing financial reports [35-38]. Considering the risks, analytical procedures are used to review audit plans to see whether they have been affected by the emergency changes [39].

Auditors can use analytical procedures during COVID-19 pandemic as companies may go bankrupt or deliberately not show their profits correctly. Therefore, analytical procedures may save costs and help analyse the institutions' financial operations relatively [40]. Also, Rose et al. [40] reported that the auditing quality may be subject to a type of concern due to the multiple interpretations when considering fraud risks. Thus, generating multiple alternative explanations may have a negative effect as it is not intended to stimulate positive thinking. Moreover, auditors may try to rely heavily on analytical procedures to gain a broader understanding of companies' financial positions and thus reduce detailed tests that require longer time and higher fees, considering that most communications during COVID-19 are done through social media programs and e-mail [7].

According to Bondarenko et al. [41], COVID-19 has a significant and negative impact on audit procedures.This requires developing alternative methods and procedures through which audit evidence can be collected in addition to the need to amend audit plans. The second hypothesis is formulated as follows:

H2. With other conditions residual the same, the COVID - 19 epidemic has harmed the audit procedures.

\section{2-3-Audit Staff Salaries}

Improving the well-being of internal auditors, selecting employees with an appropriate educational background, and strengthening the internal control system all have a positive major impact on combating corruption [42]. Among the factors that contributed to the spread of corruption are poor audit performance and Low salaries paid to emploees [43]. Increased working hours and reduced incentives for auditors are among the main reasons for the decline in audit quality [44]. As the audit work increases, the quality of the audit is low [45]. It may stated that the auditors 'salaries depend on the quality of the service provided by them and the level of satisfaction of the stakeholders with the performance. However, some studies have shown that the availability of data may be a key factor in improving the performance of auditors and thus improving the quality of auditing [8].

During the COVID-19 outbreak, some companies began to take exceptional measures and procedures to assist employees while preserving the enterprises' normal condition. On the other hand, some companies have taken things that naturally have an impact on the performance of auditing, such as laying off some employees, giving them leave without salaries, or reducing their salaries [46].

There is a lack of complete clarity about the relationship between team member salaries and audit quality. According to efficiency wage theories, the improvement of the audit is linked to wages, as the availability of significant wages may motivate auditors to perform their work accurately, or institutions may be able to obtain the services of auditors who have experience and high qualifications and who often demand significant wages in exchange for performing the audit [47]. As a result of the outbreak of COVID-19, many jobs were lost in various sectors [5]. The third hypothesis is:

H3. With other conditions residual the same, the COVID-19 epidemic has harmed the audit staff salaries.

\section{3- Methodology and Research Design}

In this study, we used two methods of data collection, questionnaires, and interviews as shown in Figure 1. Both methods were applied due to the lack of information available to the public. It has been suggested that analysis based on mixed methods, is capable of revealing the dynamic character and complexity of these approaches [48]. We attempt to combine elements of qualitative and quantitative approaches concurrently for the main purpose of extensiveness and depth of understanding and validation. The research factors were selected after reviewing some of the literature that discusses auditing under risks [49, 50], and responded to a recent call by Albitar et al. [8]. Particularly, this research evaluates the impact of COVID-19 on several auditing aspects, namely audit fees, audit procedures, and auditors' salaries. 


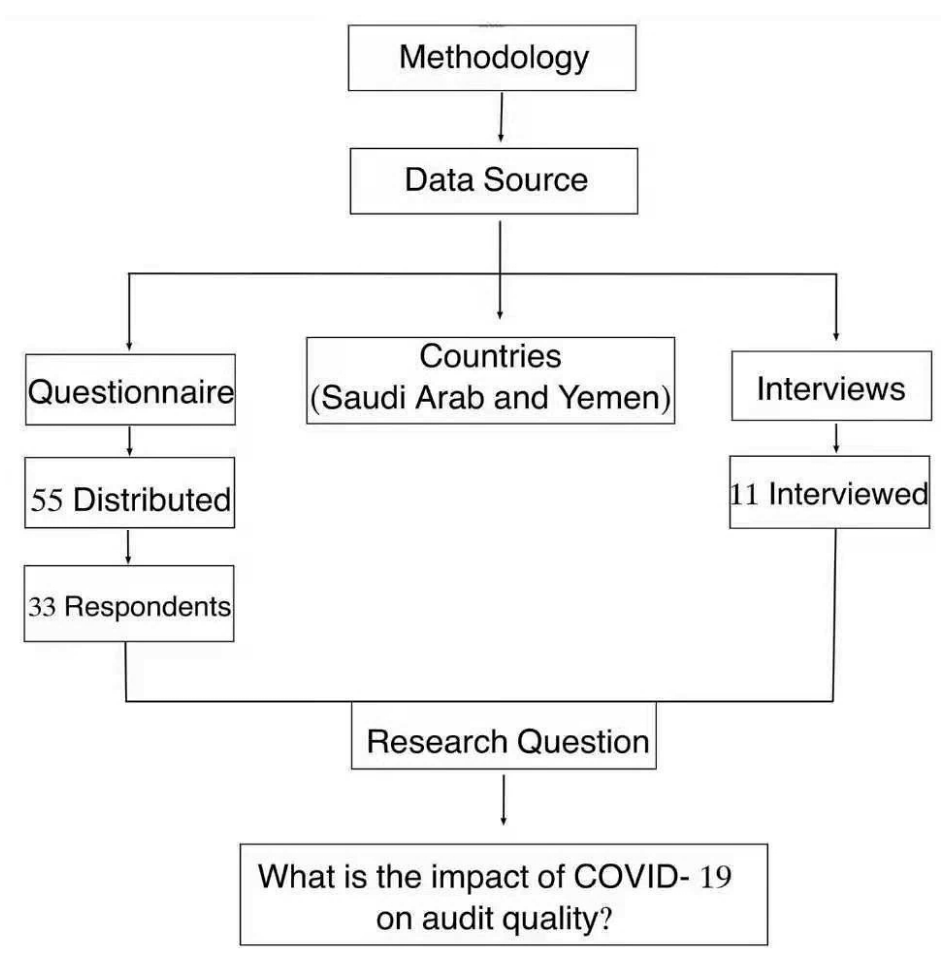

Figure 1. Flow chart of the research methodology

This research is a cross-country study and the data used were collected from two different markets, namely Saudi Arabia and Yemen. The selection of samples from two countries would enable us to provide a comparison between these markets and understand the influence of COVID-19 aspects from markets with different levels of development. For instance, it has been suggested that in Yemen, the internal audit is ineffective in the normal situation [43].

Table 1 presents a summary regarding participants in both the questionnaire and interview survey and the hypothetical means of the study and formula. As shown in Table 1, the participants involved in this study are managers of audit offices, the internal auditors, the external auditors, financial managers. In total, 55 questionnaires were distributed, and 11 interviews were conducted with the participants. To measure the impact of COVID-19 on audit fees, audit procedures, and auditors' salaries quantitatively, we used the five-point Likert scale ( 1 strongly disagree and 5 strongly agree) with 4,5, and 4 items per topic respectively. Additionally, eleven interviews were conducted online due to the lockdown measurements taken by governments. Collecting data through interviewing is one of the best methods and other research techniques related to the administrative and commercial fields. Moreover, it provides a great degree of flexibility when collecting data and analysis [51]. Using interviews to collect data gives a large space for the respondents to clarify the answers more broadly, covering full knowledge of the topic under investigation [52].

Table 1. Sample collections of the study

\begin{tabular}{|c|c|}
\hline Phase A-sample collection -questionnaires & Descriptions \\
\hline \multirow[t]{2}{*}{ Research question(s) } & $\begin{array}{l}\text { Q1. What is the impact of COVID-19 on audit quality? what is the impact of COVID } 19 \text { on audit } \\
\text { fees? what is the impact of COVID- } 19 \text { on audit procedures? what is the impact of COVID-19 on } \\
\text { audit staff remunerations? }\end{array}$ \\
\hline & Q2-What are the lessons learning from the COVID-19 pandemic? \\
\hline Number of questionnaires distributed & 55 \\
\hline Number of questionnaires retrieved & 37 \\
\hline Type of participant & 5 managers of audit offices, the internal auditors, 3 external auditors, and 6 financial managers \\
\hline Country & (20) Yemen, (17) Saudi Arabia \\
\hline The hypothetical means of the study and formula & $\begin{array}{l}3 \text {, given by } Y=1+2+3+4+5=15 \text { divided } 5=3 \text {. If the average paragraph is more than } 3 \text { it means } \\
\text { the paragraph (available) and if the average is less than } 3 \text { it means the paragraph is unavailable }\end{array}$ \\
\hline \multicolumn{2}{|r|}{ Phase B-sample collection -interviews } \\
\hline Number of interviews & 11 \\
\hline Type of participant & $\begin{array}{l}\text { (4) Managers of audit offices- (5) The internal auditors-(1) The external auditors and (1) } \\
\text { Financial managers }\end{array}$ \\
\hline Country & (6) Yemen, (5) Saudi Arabia \\
\hline Interview method & WhatsApp-Imo- \\
\hline
\end{tabular}




\section{4- Results and Discussions}

\section{4-1-Analysis of Respondents}

Table 2 shows that the response rate reached $67.27 \%$, which is considered a very high rate compared to other studies that depend on the questionnaire [53]. The reasons can be ascribed to the method of collecting the data from respondents via email. This tool has been widely used in the auditing literature [54,55]. Table 2 also contains summary statistics regarding participant professional qualifications and work experience. It reveals that most of the responses came from the internal auditors, where the percentage was $71.9 \%$ of the respondents. In comparison, managers of audit offices recorded a slight increase of $62.5 \%$, a percentage compared to the rest of the two categories (External auditors and financial managers). We expected considerable feedback from the internal auditors due to their great interest and desire to support the research. Nevertheless, we believe that the number of questionnaires retrieved from each category is sufficient to conduct the analysis and address the research questions raised in this paper as the sample is quite heterogeneous. Multiple types of respondents in terms of qualifications and work experience are represented within the sample.

Table 2. Analysis of respondents

\begin{tabular}{cccc}
\hline Type of participant & $\begin{array}{c}\text { No. of respondents that were } \\
\text { communicated }\end{array}$ & $\begin{array}{c}\text { No. of respondents that truly } \\
\text { cooperated }\end{array}$ & $\begin{array}{c}\text { \% of respondents that } \\
\text { participated }\end{array}$ \\
\hline Managers of audit offices & \multicolumn{2}{c}{ Phase A-Questionnaires } & \\
Internal auditors & 8 & $5(13.51 \%)$ & $62.5 \%$ \\
External auditors & 32 & $23(62.16 \%)$ & $71.9 \%$ \\
Financial managers & 5 & $3(8.11 \%)$ & $60 \%$ \\
Total & 10 & $6(16.22 \%)$ & $60 \%$ \\
\hline
\end{tabular}

\section{4-2-Results and Discussion of the Questionnaire}

\section{4-2-1- COVID-19 and Audit Fees}

Table 3 shows that the average of the first hypothesis reached 3.32 which is higher than the hypothetical means of study 3 . This indicates that COVID-19 has a significant impact on audit fees. The standard deviation reached 0.95 , which indicates that the respondents' opinions are not dispersed and clear. The evaluation of the impact of COVID-19 on the audit fee was measured through 4 items, as shown in Table 3, where the effect of items was classified according to the value of the arithmetic average. The first item came in first place with an average of 3.97, which is more than the study's general average. This is an indication that low liquidity due to an impact on all economic sectors was one reason for the decrease in audit fees. According to Chen et al. [1], the unexpected economic conditions represent a major challenge for companies and stakeholders, as changes affect liquidity, leading to higher audit fees. Liquidity is one of the most important pillars in the light of which audit fees can be determined, and it is also one of the most important indicators of the improvement in the performance of companies.

Table 3. Results of the questionnaire concerning the impact of COVID -19 on audit fees

\begin{tabular}{|c|c|c|c|c|c|c|c|c|}
\hline No & Statements & Min & $\operatorname{Max}$ & Mean & $\begin{array}{l}\text { Std. } \\
\text { Dev. }\end{array}$ & $\begin{array}{l}\text { Present age } \\
\text { rating } 1 \text { or } 2\end{array}$ & $\begin{array}{l}\text { Present age } \\
\text { rating 4or } 5\end{array}$ & Rank \\
\hline 1 & $\begin{array}{l}\text { The COVID-19 negatively affected the liquidity of institutions, } \\
\text { which led to demands to reduce audit fees }\end{array}$ & 2 & 5 & 3.97 & 0.799 & 5.40 & 81.01 & 1 \\
\hline 2 & $\begin{array}{l}\text { The COVID-19 didn't affect the selling and purchasing power of } \\
\text { institutions }\end{array}$ & 1 & 5 & 2.92 & 1.038 & 32.43 & 29.73 & 4 \\
\hline 3 & $\begin{array}{l}\text { The absence of enforcement of laws and standards regulating the } \\
\text { relationship between institutions and auditors greatly contributed to } \\
\text { reducing audit fees during the COVID-19 period. }\end{array}$ & 1 & 5 & 3.27 & 1.018 & 21.62 & 45.94 & 2 \\
\hline \multirow[t]{2}{*}{4} & $\begin{array}{l}\text { The large number of auditors resulting from layoffs from companies } \\
\text { is one of the reasons for the low audit fees }\end{array}$ & 1 & 5 & 3.14 & 0.976 & 27.02 & 35.13 & 3 \\
\hline & Average Mean and Std.Dev & & & & & 0.96 & & \\
\hline
\end{tabular}

The third item came second with an average of 3.27, which is more than the general average for the study. This indicates that the absence of the application of standards and laws regulating the relationship between institutions and audit offices has dramatically affected the reduction of audit fees due to the stakeholders' lack of fear of the effects that they may face in the event of non-compliance with them. According to Makni Fourati and Bougacha [56], the implementation of international standards contributes to maintaining audit fees and may increase. 
Regarding statement no.4, it was ranked $4^{\text {th }}$ with an average of of 3.14 , which is more than the study's general average. This indicates that the presence of many auditors without work because of being dismissed from companies was one of the reasons for the impact of the COVID-19 on audit fees. This corresponds to the law of supply and demand. In their study, Maher et al. [57] showed that auditing fees decreased significantly during the years 1977-19821, and the reason was attributed to the increase in competition and the abundance of auditors in the auditing market to provide services to clients because of the economic downturn. According to Krishnan and Zhang [58] during the 2007-2008 financial crisis, many institutions in 2008-2009 were able to obtain audit services at lower fees.

The second statement received the least average of 2.92, which is less than the study's general average. This indicates that the decline in the purchasing and selling power of institutions and companies due to applying the precautionary measures imposed by countries to slow the transmission of the COVID-19 has affected the audit fees. As a result of the significant impact of COVID-19 on organizations' financial operations, audit firms may come under pressure from the institutions they work with to reduce audit fees [8]. Thus, the decrease in audit fees due to the COVID-19 outbreak has significantly affected audit quality.

\section{4-2-2- COVID-19 and Audit Procedures}

Table 4 shows that the average of the second hypothesis reached 3.54 which is higher than the hypothetical means of study 3. This is an indication that COVID-19 has a significant negative impact on audit procedures. Standard deviation reached 0.910 , which indicates that the respondents' opinions are not dispersed and clear. The evaluation of the impact of COVID-19 on the audit fee was measured through 5 items as shown in Table 4, where the effect of items was classified according to the value of the arithmetic average. Also, consideration is given to the percentage of respondents, which is used to measure the percentage of the effect.

Table 4. Results of the questionnaire concerning the impact of COVID -19 on audit procedures

\begin{tabular}{|c|c|c|c|c|c|c|c|c|}
\hline No & Statement & Min & $\operatorname{Max}$ & Mean & $\begin{array}{l}\text { Std. } \\
\text { Dev }\end{array}$ & $\begin{array}{l}\text { Present age } \\
\text { rating } 1 \text { or } 2\end{array}$ & $\begin{array}{l}\text { Present age } \\
\text { rating 4or } 5\end{array}$ & Rank \\
\hline 1 & $\begin{array}{l}\text { The absence of modern systems and the reliance on social media } \\
\text { only affected the confidence of the data obtained }\end{array}$ & 2 & 5 & 3.76 & 1.038 & 29.78 & 70.28 & 3 \\
\hline 2 & $\begin{array}{l}\text { The use of analytical procedures to verify audit procedures gave } \\
\text { the same result when performing traditional audit procedures }\end{array}$ & 1 & 4 & 2.14 & 1.032 & 72.97 & 16.21 & 5 \\
\hline 3 & $\begin{array}{l}\text { The risk from the COVID-19 outbreak affected disorganization } \\
\text { and anxiety among auditors }\end{array}$ & 1 & 5 & 3.51 & 1.146 & 18.9 & 62.16 & 4 \\
\hline 4 & $\begin{array}{l}\text { The time allocated to implementing audit procedures has } \\
\text { increased during the outbreak of the COVID- } 19 \text {. }\end{array}$ & 2 & 5 & 4.03 & 0.645 & 2.70 & 86.48 & 2 \\
\hline \multirow[t]{2}{*}{5} & $\begin{array}{l}\text { The COVID- } 19 \text { has negatively affected the method of gathering } \\
\text { and verifying audit evidence }\end{array}$ & 2 & 5 & 4.27 & 0.693 & 2.70 & $91.89 \mathrm{~s}$ & 1 \\
\hline & Average Mean and Std.Dev & & & & & 0.96 & & \\
\hline
\end{tabular}

The fifth statement has an average of 4.27, which is more than the general average for the study. It is a result of the preventive measures and the implementation of work from home and the inability to implement the audit procedures, starting with the development of plans, examination, and surveying so, the confidence in the data obtained was insufficient. If the information is not obtained accurately and with high reliability, the risk of issuing a false audit opinion is high [40].

In addition, examining the percentage of respondents, 70.28 agreed and strongly agreed, which is used to measure the extent of the impact of the absence of modern auditing systems on the reliability of the data. The fourth item came first with an average of 4.03, which is more than the general average for the study. This indicates that the time allocated to implementing audit procedures has increased during the outbreak of the COVID-19. During risks, auditors are increasing their efforts and energy allocated to auditing to protect themselves from risks [59]. According to PWC [60], it is necessary to increase the auditing times during the COVID-19 outbreak.

The first item was ranked third with an average of 3.76, which is more than the study's general average. This indicates that the absence of modern systems and the reliance on social media affected the data's confidence. The third item is ranked fourth with an average of 3.51, which is more than the study's general average. This indicates that the risk from the COVID-19 outbreak affected disorganization and anxiety among auditors. Considering the risks, the audit quality is subject to a kind of distrust and growing anxiety because of multiple interpretations under changing circumstances [31].

The second item has an average of 2.14, which is less than the study's general average. This indicates that analytical procedures to verify audit procedures didn't give the same result when performing traditional audit procedures. During an outbreak, audits are incredibly complex due to a high level of uncertainty, and thus the results may be uncertain[7]. 
Because the audit function requires many stages such as examination, field visits, and matching with customers, the audit procedures that were followed during the COVID-19 outbreak did not give the same result of reliability when following the traditional methods. Considering the precautionary measures during COVID-19 and resulting in an almost complete suspension of movement, the use of official documents that are used in financial operations, for example, reduced the original invoices, receipts, exchange vouchers, supply, and exchange orders, etc. Thus, the institutions used the documents sent through social media, including the mail. As a result, the work-from-home routine affected the reliability and adequacy of audit evidence, leading to an impact on the quality of the audit [7].

\section{4-2-3- COVID-19 and Staff Salaries}

Table 5 shows that the third hypothesis reached 3.81 which is higher than the hypothetical means of study 3 . This is an indication that COVID-19 has a significant impact on audit staff salaries.

Table 5. Results of the questionnaire concerning the impact of COVID -19 on staff salaries

\begin{tabular}{|c|c|c|c|c|c|c|c|c|}
\hline No & Statement & Min & $\operatorname{Max}$ & Mean & $\begin{array}{l}\text { Std. } \\
\text { Dev }\end{array}$ & $\begin{array}{l}\text { Present age } \\
\text { rating } 1 \text { or } 2\end{array}$ & $\begin{array}{l}\text { Present age } \\
\text { rating 4or } 5\end{array}$ & Rank \\
\hline 1 & $\begin{array}{l}\text { The salaries provided to the auditors decreased during the } \\
\text { COVID-19 outbreak }\end{array}$ & 2 & 5 & 4.05 & 0.880 & 5.40 & 75.67 & 1 \\
\hline 2 & $\begin{array}{l}\text { Auditors faced a challenge while requiring organizations to pay for } \\
\text { work during risks }\end{array}$ & 1 & 5 & 3.43 & 0.899 & 18.91 & 62.16 & 5 \\
\hline 3 & $\begin{array}{l}\text { The auditors were asked to increase the time specified for auditing } \\
\text { without material charge for the added time }\end{array}$ & 1 & 5 & 4.01 & 0.913 & 5.40 & 78.38 & 2 \\
\hline 4 & $\begin{array}{l}\text { Due to the result of COVID- } 19 \text { on the financial operations of the } \\
\text { institutions, there was a delay in receiving the salary }\end{array}$ & 1 & 5 & 3.81 & 0.877 & 5.40 & 70.27 & 3 \\
\hline \multirow[t]{2}{*}{5} & $\begin{array}{l}\text { The institutions stopped paying the rewards and incentives that } \\
\text { were accustomed to them by the auditors, which contributed to the } \\
\text { failure to perform the audit well }\end{array}$ & 2 & 5 & 3.76 & 0.683 & 2.70 & 67.56 & 4 \\
\hline & Average Mean and Std.Dev & & & & & 3.81 & & \\
\hline
\end{tabular}

The first item came first with an average of 4.05, which is more than the study's general average. This indicates that employees' salaries have been affected due to the impact of COVID-19 on financial operations and the suspension of the buying and selling process. As a result of the negative impact of economic operations, some companies had to take some, including reducing salaries or granting employees unpaid leave [46].

The third item as shown on the table received an average of 3.81, which is more than the study's general average. This indicates the auditors were asked to increase the time specified for auditing without material charge for the added time. One of the main reasons for the low quality of auditing is the increase in working hours and the reduction of incentives [44].

The fourth item was ranked third with an average of 3.76, which is more than the study's general average. This indicates that because of the institutions' financial operations, there was a delay in receiving the salary. The last item is ranked fourth with an average of 3.76 which is more than the general average of the study which indicates that the institutions stopped paying the rewards and incentives that were accustomed to them by the auditors, which contributed to the failure to perform the audit well.

The second item as shown on the table is fifth with an average of 3.43, which is more than the general average of the study. This indicates that auditors faced a challenge while requiring organizations to pay for work during risks. This is confirmed by Deloitte [46]. As a result of the reasons discussed in the above studies, COVID-19 has affected audit employees' salaries, leading to a negative impact on audit performance. As the incentives and encouragement motives for auditors are not available, there are no motives that enable them to perform their work most effectively and efficiently [8]. Thus, any manipulation of employees' rights in salaries and bonuses leads to an impact on the quality of the audit.

It is evident from table 6 that the impact of COVID -19 on the factors that contribute to increasing the quality of the audit was large and in close proportions on all factors. This is an indication that improving the quality of internal audit is related to many factors, whether these factors are related to the auditors, clients, as well as procedures. Finally, in Table 6, it becomes clear that the effect of COVID-19 on all the factors that were investigated was significant, especially about employees' salaries and human capital. Many reasons led to this, including a decrease in the purchasing and selling power, a halt in production, practice auditing from homes, a decrease in revenues. In addition to the abundance of auditors in the market as a result of some institutions dispensing with some auditors. 
Table 6. Results of the questionnaire concerning COVID-19

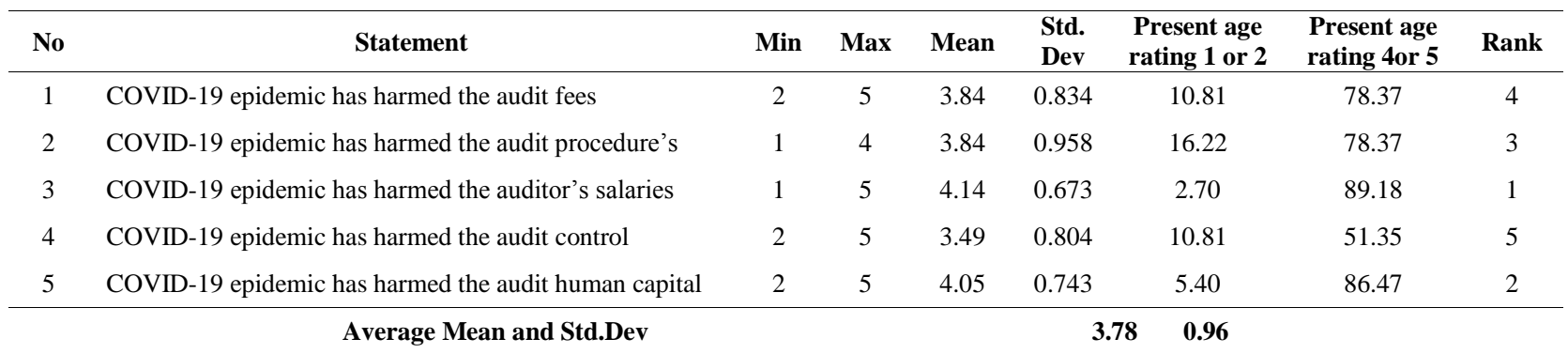

\section{4-2-4- Correlation and Regression}

Table 7 shows the correlation matrix which has been used in this study to identify the degree of correlation between the variables. It shows that the CO is significantly correlated with all variables. The IAFE, IAPR, IASA (P-value $<.01$ and $\mathrm{p}<.05)$, and IASA is insignificantly correlated with the $\mathrm{CO}(\mathrm{P}<.01)$.

Table 7. Pearsonscorrelationion coefficient

\begin{tabular}{cccccc}
\hline No & Variable & $\mathbf{1}$ & $\mathbf{2}$ & $\mathbf{3}$ & $\mathbf{4}$ \\
\hline 1 & CO & 1.00 & & & \\
2 & IAFE & $0.424^{* *}$ & 1.00 & & \\
3 & IAPR & $0.482^{* *}$ & $0.764^{* *}$ & 1.00 & \\
4 & IASA & 0.083 & $-0.327^{*}$ & -0.174 & 1.00 \\
\hline
\end{tabular}

Notes: CO (COVID-19)- IAFE (Internal audit fees)- IAPR (Internal audit procedure's)- IASA (Internal auditors' salaries)

**. Correlation is significant at the 0.01 level (2-tailed)

*. Correlation is significant at the 0.05 level (2-tailed).

Table 8 shows the results of regression analysis between variables. The results generally show that there is significance at $\mathrm{P}<0.01$ with an adjusted $\mathrm{R}^{2}=0.24$. The results of the IAFE coefficient indicate that there is a critical correlation ( H1 supported). This is an indication that audit fees are linked to an impact of CO on institutions. The results also showed a significant association between the $\mathrm{CO}$ and IAPR with $\mathrm{P}<0.01$ (H2 supported).

Table 8. Regression and T-test analysis

\begin{tabular}{|c|c|c|c|c|c|c|c|}
\hline \multirow{2}{*}{ Model } & \multicolumn{2}{|c|}{ Unstandardized Coefficients } & \multirow{2}{*}{$\begin{array}{c}\text { Standardized Coefficients } \\
\text { Beta }\end{array}$} & \multirow{2}{*}{$\begin{array}{c}\text { T- } \\
\text { statistic }\end{array}$} & \multirow{2}{*}{ Sig. } & \multicolumn{2}{|c|}{ Collinearity Statistics } \\
\hline & B & Std. Error & & & & Tolerance & $\mathbf{F}$ \\
\hline Constant & 1.533 & 1.518 & & 1.010 & 0.320 & & \\
\hline IAFE & 0.535 & 0.244 & .378 & 2.194 & 0.036 & 0.826 & 1.947 \\
\hline Constant & 1.380 & 1.030 & & 1.340 & 0.190 & & \\
\hline IAPR & 0.403 & 0.165 & .396 & 2.433 & 0.021 & 0.826 & 2.956 \\
\hline Constant & 3.901 & 1.028 & & 3.797 & 0.001 & & \\
\hline IASA & 0.042 & 0.165 & .046 & 0.252 & 0.803 & 0.826 & 0.958 \\
\hline
\end{tabular}

$\mathrm{R} 2=0.24$, Adjusted R Square $=0.32 \mathrm{P}<0.01$

Of the underlying factors, IAPR has been affected mainly by CO with $\beta=.396$ for the IASA coefficients, the results show a significant correlation but not like the other hypothesis at $\mathrm{P}<0.05$ ( $\mathrm{H} 3$ supported). T-test indicates differences in relating to two of the three hypotheses $(\mathrm{H} 1$ and $\mathrm{H} 2)$. But the result showed that there are no significant differences at the aggregate level of the third hypothesis. Overall, our results showed that the COVID-19 affects all three factors (IAFE, IAPR, and IASA)with different levels of the effect.

\section{4-3-Result and Discussion of the Interviews}

\section{4-3-1- Main findings of the Present Study}

It is evident from Table 9 that the impact of COVID-19 on the quality of auditing is significant, especially considering the weak conditions of the audit system in the normal situation and the family ownership of institutions. Considering the turbulent economic conditions, family businesses may be exposed to more risks than regular companies due to the 
possibility of the absence of a qualified administration or failure to separate the top management from the rest of the departments, which may reduce the quality of work and thus incur higher costs [61].

During any economic crisis, family business owners usually resort to reducing work costs, and therefore, company owners may work in several locations as a manager, financial controller, or dismissal of the external auditor. This may lead to an inflated risk to companies and a decrease in the quality of auditing, causing poor performance of companies [62].

Table 9 also shows that some Yemen and Saudi Arabia institutions called on audit offices to reduce audit fees. Therefore, auditors may be affected by the decrease in their salaries, which makes them feel job dissatisfied, exposning accompanies risks to audit quality by not fully and accurately implementing audit procedures. This may be due to several reasons, including the lack of specific standards and regulations to deal with emergencies which require organizations interested in auditing to establish clear and specific foundations and standards for how to exercise audit functions in light of crises. In addition, the governmental and supervisory authorities must issue legislation that would also regulate the work and the relationship between institutions and auditors in various cases. The results of the interview also indicate that the weakness of the general audit system used in Yemen was one of the main and important reasons for the damage to the audit system from COVID-19. As the absence of laws regulating the relationship between auditors and institutions has resulted in auditors being greatly affected in terms of reducing salaries, dispensing with auditors by institutions, or requesting to postpone the delivery of salaries, which may negatively affect the exercise of internal audit functions in the manner defined by the organizing organizations for these occupations Figure 2 also presents the summery of the results regarding the impact of COVID-19.

Table 9. Results of the interviews

\section{Direct quotation from respondents}

(1) Some institutions have requested audit offices to reduce audit fees while asking them to increase audit time to avoid risks.

(2) Some auditors were dispensed with, and accountants cover the auditor's work in small and family companies.

Respondents from (3) Audit procedures have shrunk dramatically, which used to rely on large operations, starting with the initial survey, Saudi Arabia planning the audit process, going to the field, looking for evidence for auditing, evaluating the control work, and following up, to relying on new methods such as communication via e-mail or social media.

(4) Significantly failure to perform the audit function in the manner specified by the Institute of Internal Auditors, causing errors that affected audit performance.

(1) Individual and family institutions have asked the audit offices to stop auditing operating.

(2) Reducing audit fees by up to $40 \%$ in regular and large institutions

Respondents from Yemen

(3) Significant reduction in auditing procedures and reliance on e-mail

(4) Cut out many reviewers

(5) In the absence of modern systems in commercial institutions, confidence in the data was insufficient

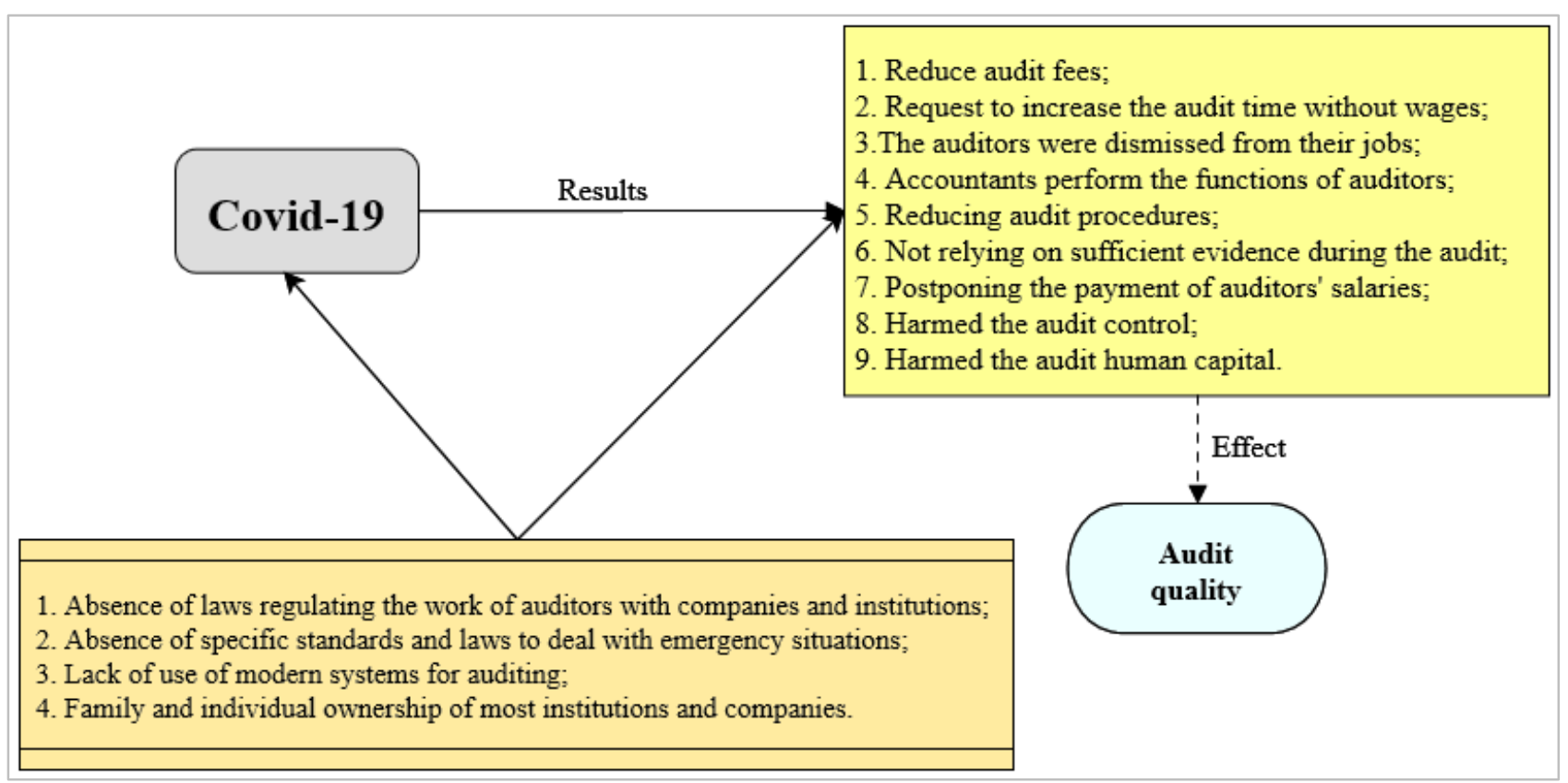

Figure 2. Summery of the results regarding the impact of COVID-19 


\section{4-3-2- Comparison with Other Studies}

The results of this study are contrary to what some studies have shown in the case of increasing risks to companies. Audit fees rise due to the need for more auditors in terms of numbers, spending more time in the investigation and searching for evidence, and examining a large sample. According to the results of the present study, during the unstable economic situation, companies work to reduce risks in order to avoid audit failure, which requires an increase in auditors, examining the most significant amount of data, spending more time at work [63]. Bell et al. [24] concluded that during risks, auditors spend more time on work, which requires raising audit fees. During crises, companies seek more qualified and experienced auditors, which contributes to raising audit fees [64]. Consequently, we argue that COVID-19 greatly affected the decline in audit fees and the inadequate procedures used to verify the data, in addition to the impact on the salaries of auditors, which led to poor audit quality. As for the results of a study by Albitar et al. [8] in which content analysis and the authors' point of view were used based on the analysis of reports issued by some auditing companies, especially the four major auditing companies, they are consistent with the results of this study in terms of the significant impact of Covid 19 on several elements, namely, audit procedures, audit fees, audit Human capital, as well as employee salaries, which leads to a significant and profound impact on audit performance and quality. In their study, Hay et al. [65] showed that the COVID19 crisis had a non-significant impact on audit reports and financial reports. On the other hand, our results are consistent with the results by Castka et al. [5] which showed that the impact of COVID-19 on the audit practice was significant, as the traditional audit practice was reduced, which may require a long period to know the results of the non-traditional audit practice. The method of analysis may differ because this study is based on the questionnaire and the interview. Some of the previous studies were based on analysing the point of view or analysing reports issued by organizations that are interested in auditing.

\section{4-3-3- Implications and Limitations of the Study}

This study has an important implication for the profession of auditing, auditing offices, and auditors. Auditors may demand an increase in audit fees during the COVID-19 outbreak. During the financial crisis that occurred in 2007-2008, audit fees that companies paid to auditors, especially the auditors of the Big Four audit firms, increased. This crisis, however, is different in in all aspects. The results of our study proved the opposite. The results show that during the spread of COVID-19 audit fees significantly decreased. Considering the spread of a virus and the continuation of work through electronic programs and artificial intelligence in addition to network security, it is expected that good use of these programs may improve the communication relationship between auditors and related parties. Consequently, the audit performance may improve positively, which enhances the performance of companies.

One of the most important limitations of this study is the geographical representation. The questionnaire was distributed in two countries only and specific respondent groups. Therefore, future studies may expand access to data from several countries, such as the countries of the Arab region completely or the countries of the Gulf Cooperation Council.

\section{4-3-4- COVID-19 and Auditing: Lessons and Opportunities}

To understand the impact of COVID-19 on audit quality, it may be exaggerated to consider economic and financial factors as the main reason affecting the audit quality. However, it is regarded as an essential external factor for the failure of the system of internal governance for institutions. Thus, many lessons are emerging from the spread of COVID-19. First, the system of corporate internal control may be seen as incomplete and a lack of corporate governance. Secondly, there may be a need to develop standards that are commensurate with unexpected situations, and therefore the bodies that legislate auditing standards may consider this matter. Some lessons learned from work under COVID-19 and instructions that auditors should deal with in the following points.

- The risks of COVID-19 affecting companies and institutions increased as a result of the weakness in the internal governance system, and this is noticeable in the results of the interviews, especially in Yemen.

- Significant audit risks arising from not taking advantage of opportunities may affect corporate governance.

- Companies did not learn as required from the 2007-2008 crisis to set up an emergency program to prepare for all eventualities without affecting their overall performance.

- The negative factors that affected the auditing quality may be related primarily to management, auditors, and not procedures.

- The great impact of COVID-19 on the audit quality was linked to the weakness of the audit system and the lack of modern systems. In addition, there is a possibility that the deteriorating economic situation of the state was directly related to the failure of the audit.

- There is a necessity of making changes in the auditors' responsibilities in proportion to the situation that achieves the public interests of the institutions [65].

- During the COVID-19 crisis, the role of the internal auditor can be strengthened through (i) An attempt to establish an integrated business risk management and increase the organization's operations (ii) The internal auditor must 
enhance the capabilities by obtaining the data that the internal audit used during COVID-19 outbreak such as assessing the institution's capacity, evaluating cooperation with other departments, such as risk management, the role of shareholders in mitigating impacts, and thus it is possible by looking at this data and its results to obtain some results that may benefit the auditor in the future (iii) About the development that the audit must work on is the shift from performing the usual or traditional functions to the performance of risk-based functions.

Consequently, auditors must ensure that the specified procedures for corporate governance and risk management are followed carefully. In addition to that, they must follow the operational work on a daily and continuous basis. While departments should see other companies' departments that are more efficient and work to exploit the positive points in addition, the focus should be on the human factor as the most important factor in institutions as a key to success or failure. The audit committees should also be highlighted, and communication should be activated between them and management, as well as the auditors. We believe that the audit committees' efficiency may contribute in some way to mitigating the effects of the crisis. This is also confirmed by Khatib and Nour [2].

In conclusion, the opportunity provided by the crisis created a wide-ranging reflection on the external and internal auditors, in addition to being an essential source of feedback that enables all parties to correct the weaknesses that appeared and work to improve the risk management and governance system to avoid these problems in the future.

\section{5- Conclusion, Recommendations and Future Direction}

The health crisis of the coronavirus outbreak has severely affected economies and corporations around the globe. In this paper, we empirically examined the impact of COVID-19 on audit quality, and three auditing attributes were subjected to this investigation, namely audit fees, audit procedures, and auditors' salaries. Two methods of data collection (questionnaires and interviews) were utilized to collect data from two different markets, namely Saudi Arabia and Yemen. The participants involved in this study are managers of audit offices, internal auditors, external auditors, and financial managers.

Our investigation revealed that the impact of COVID-19 on audit fees was significant, especially considering family ownership of institutions and the absence of laws that control and determine audit fees in light of crises. Similarly, the results showed that the audit procedures have become insufficient to obtain evidence and sufficient data required for the auditing process. Consequently, the precautionary measures were a great reason for not practicing the traditional audit procedures that institutions follow to obtain genuine financial information, which negatively affected the audit quality. Declining corporate revenues and challenges to companies' operation processes due to lockdown policies were reasons for dismissing the auditors in some institutions or laying off some of them, which was a reason for the decline in auditing quality.

Additionally, our results highlighted the audit system's weaknesses, the absence of governance, the failure to follow international standards, insufficient evidence, and low reliability when investigating data as among the factors that have contributed to reducing the quality of auditing during the outbreak of COVID-19. We recommend that companies and institutions take advantage of this crisis to improve the effectiveness of auditing in the future. The use of modern systems and technological means, such as artificial intelligence and the development of network security, will help enterprises in the future avoid the same problems that have occurred recently. Moreover, audits should be activated based on risk. Some may consider the effects of COVID-19 to be $100 \%$ devastating. Nonetheless, institutions that follow a specific system and have strong administrations will turn weakness into an opportunity to benefit from in building strong audit programs in the future.

This research suggests several opportunities for further investigation. Researchers can discuss the economic impact on the quality of auditing during the COVID-19 outbreak, in addition to discussing the laws that control audit fees and procedures and their consequences on the quality of auditing. More empirical research could evaluate the impact of the COVID-19 outbreak on corporate financial reporting and auditing associations. On the other hand, future studies can discuss the lessons learned from the current situation and the relationship between international standards that regulate the audit profession in maintaining audit performance with minimal losses. What is the effect of COVID-19 on the human capital audit? What are the effects of COVID-19 on continuity auditing? Do the professional standards that regulate the audit process consider such circumstances, or is there a need to issue or develop new standards? Future studies may also look at the impact of COVID-19 on family businesses and compare them with non-family firms.

\section{6- Declarations}

\section{6-1-Author Contributions}

Conceptualization, S.A.H.; methodology, S.A.H., M.I.T., S.F.A.K.; data curation, S.A.H.; writing-original draft preparation, S.A.H.; writing-review and editing, S.A.H., M.I.T., A.A.A.R., S.F.A.K., J.Z., and H.G.C.; visualization, M.I.T., A.A.A.R., and J.Z.; supervision, J.Z., and H.G.C. All authors have read and agreed to the published version of the manuscript. 


\section{6-2-Data Availability Statement}

The data presented in this study are available on request from the corresponding author.

\section{6-3- Funding}

The authors received no financial support for the research, authorship, and/or publication of this article.

\section{6-4- Conflicts of Interest}

The authors declare that there is no conflict of interests regarding the publication of this manuscript. In addition, the ethical issues, including plagiarism, informed consent, misconduct, data fabrication and/or falsification, double publication and/or submission, and redundancies have been completely observed by the authors.

\section{7- References}

[1] Chen, H., Hua, S., Liu, Z., \& Zhang, M. (2019). Audit fees, perceived audit risk, and the financial crisis of 2008. Asian Review of Accounting, 27(1), 97-111. doi:10.1108/ARA-01-2017-0007.

[2] Khatib, S. F. A., \& Nour, A. N. I. (2021). The Impact of Corporate Governance on Firm Performance During The COVID-19 Pandemic: Evidence from Malaysia. Journal of Asian Finance, Economics and Business, 8(2), $943-952$. doi:10.13106/jafeb.2021.vol8.no2.0943.

[3] Ashraf, B. N. (2020). Economic impact of government interventions during the COVID-19 pandemic: International evidence from financial markets. Journal of Behavioral and Experimental Finance, 27, 100371. doi:10.1016/j.jbef.2020.100371.

[4] Abate, M., Christidis, P., \& Purwanto, A. J. (2020). Government support to airlines in the aftermath of the COVID-19 pandemic. Journal of Air Transport Management, 89(June), 101931. doi:10.1016/j.jairtraman.2020.101931.

[5] Castka, P., Searcy, C., \& Fischer, S. (2020). Technology-enhanced auditing in voluntary sustainability standards: The impact of COVID-19. Sustainability (Switzerland), 12(11), 1-24,. doi:10.3390/su12114740.

[6] Goodell, J. W. (2020). COVID-19 and finance: Agendas for future research. Finance Research Letters, $35,101512$. doi:10.1016/j.frl.2020.101512.

[7] KMPG International. (2020). COVID-19: Potential Impact on Financial Reporting. In KPMG Josh (pp. 1-7). Available online: https://assets.kpmg/content/dam/kpmg/in/pdf/2020/03/firstnotes-covid-19-potential-impact-on-financial-reporting.pdf (accessed on December 2021).

[8] Albitar, K., Gerged, A. M., Kikhia, H., \& Hussainey, K. (2021). Auditing in times of social distancing: the effect of COVID-19 on auditing quality. International Journal of Accounting and Information Management, 29(1), 169-178. doi:10.1108/IJAIM-082020-0128.

[9] Levy, H. B. (2020). Financial Reporting and Auditing Implications of the COVID-19 Pandemic. CPA Journal, 90(5), 26-33.

[10] Lenz, R., \& Hahn, U. (2015). A synthesis of empirical internal audit effectiveness literature pointing to new research opportunities. Managerial Auditing Journal, 30(1), 5-33. doi:10.1108/MAJ-08-2014-1072.

[11] Gerged, A. M., Mahamat, B. B., \& Elmghaamez, I. K. (2020). Did corporate governance compliance have an impact on auditor selection and quality? Evidence from FTSE 350. International Journal of Disclosure and Governance, 17(2-3), 51-60. doi:10.1057/s41310-020-00074-1.

[12] Hazaea, S. A., Zhu, J., Khatib, S. F., Bazhair, A. H., \& Elamer, A. A. (2021). Sustainability assurance practices: A systematic review and future research agenda. Environmental Science and Pollution Research, 1-22. doi: 10.1007/s11356-021-17359-9.

[13] Boyack, W. (2020). Guidance on audit issues arising from the COVID-19 (Coronavirus) pandemic. In Financial Reporting Council (Issue 1, pp. 1-4). Available online: https://www.frc.org.uk/news/march-2020-(1)/guidance-on-audit-issues-arisingfrom-the-covid-19 (accessed on December 2021).

[14] Eulerich, M., Wagener, M., \& Wood, D. A. (2021). Evidence on Internal Audit Effectiveness from Transitioning to Remote Audits Because of COVID-19. SSRN Electronic Journal. doi:10.2139/ssrn.3774050.

[15] Zhang, T., \& Huang, J. (2013). The Risk Premium of Audit Fee: Evidence from the 2008 Financial Crisis. China Journal of Accounting Studies, 1(1), 47-61. doi:10.1080/21697221.2013.781766.

[16] Khatib, S. F. A., Abdullah, D. F., Elamer, A., \& Hazaea, S. A. (2022). The development of corporate governance literature in Malaysia: a systematic literature review and research agenda. Corporate Governance: The International Journal of Business in Society, ahead-of-print(ahead-of-print). doi:10.1108/cg-12-2020-0565.

[17] Hazaea, S. A., Zhu, J., Al-Matari, E. M., Senan, N. A. M., Khatib, S. F. A., \& Ullah, S. (2021). Mapping of internal audit research in China: A systematic literature review and future research agenda. Cogent Business and Management, 8(1), 1938351. doi:10.1080/23311975.2021.1938351. 
[18] Homayoun, S., \& Hakimzadeh, M. (2017). Audit Fee and Audit Quality: An Empirical Analysis in Family Firms. International Journal of Economics and Financial Issues, 7(2), 469-476.

[19] Khatib, S. F. A., Abdullah, D. F., Hendrawaty, E., \& Elamer, A. A. (2021). A bibliometric analysis of cash holdings literature: current status, development, and agenda for future research. Management Review Quarterly, ead of p, no. doi:10.1007/s11301021-00213-0.

[20] Al Amosh, H., \& Khatib, S. F. A. (2021). Corporate governance and voluntary disclosure of sustainability performance: the case of Jordan. SN Business \& Economics, 1(12), 1-22,. doi:10.1007/s43546-021-00167-1.

[21] Kinney, W. R., \& Libby, R. (2002). The Relation between Auditors' Fees for Nonaudit Services and Earnings Management: Discussion. The Accounting Review, 77, 107-114. Available online: http://www.jstor.org/stable/3203327 (accessed on December 2021).

[22] Houston, R. W., Peters, M. F., \& Pratt, J. H. (1999). The audit risk model, business risk and audit-planning decisions. Accounting Review, 74(3), 281-298. doi:10.2308/accr.1999.74.3.281.

[23] Trujillo-Ponce, A., Samaniego-Medina, R., \& Cardone-Riportella, C. (2014). Examining what best explains corporate credit risk: accounting-based versus market-based models. Journal of Business Economics and Management, 15(2), $253-276$. doi:10.3846/16111699.2012.720598.

[24] Bell, T. B., Landsman, W. R., \& Shackelford, D. A. (2001). Auditors' perceived business risk and audit fees: Analysis and evidence. Journal of Accounting Research, 39(1), 35-43. doi:10.1111/1475-679X.00002.

[25] Niemi, L. (2002). Do firms pay for audit risk? Evidence on risk premiums in audit fees after direct control for audit effort. International Journal of Auditing, 6(1), 37-51. doi:10.1111/j.1099-1123.2002.tb00004.x.

[26] ABDEL-KHALIK, A. R. (1990). The jointness of audit fees and demand for MAS: A self-selection analysis. Contemporary Accounting Research, 6(2), 295-322. doi:10.1111/j.1911-3846.1990.tb00760.x.

[27] Xu, Y., Jiang, A. L., Fargher, N., \& Carson, E. (2011). Audit Reports in Australia during the Global Financial Crisis. Australian Accounting Review, 21(1), 22-31. doi:10.1111/j.1835-2561.2010.00118.x.

[28] Karim, A. W., \& Zijl, T. Van. (2013). Efficiency and opportunism in auditor quality choice in emerging audit services markets: The case of Bangladesh. International Journal of Accounting and Information Management, 21(3), $241-256$. doi:10.1108/IJAIM-08-2011-0027.

[29] Reyes, M. Implications of Covid- 19 on Auditor' s Reporting Abstrak (Vol. 5, Issue 1, pp. 59-67,).

[30] Hirst, D. E., \& Koonce, L. (1996). Audit analytical procedures: A field investigation. Contemporary Accounting Research, 13(2), 457-486. doi:10.1111/j.1911-3846.1996.tb00511.x.

[31] Rose, A. M., Rose, J. M., Suh, I., \& Thibodeau, J. C. (2020). Analytical procedures: Are more good ideas always better for audit quality? Behavioral Research in Accounting, 32(1), 37-49. doi:10.2308/bria-52512.

[32] Eugene, L., Harwood, G. B., Katz, J. L., \& Berry, L. E. (2008). Performance by of Auditing Procedures Some Governmental Auditors : Preliminary Evidence. Forum American Bar Association, 62(1), 14-28.

[33] Liu, J., Seng Woo, H., \& Boakye-Bonsu, V. (1997). Developing internal auditing procedures in UK organizations using a benchmarking approach. Managerial Auditing Journal, 12(9), 464-478. doi:10.1108/02686909710185198.

[34] Wright, A., \& Ashton, R. H. (1989). Identifying audit adjustments with attention-directing procedures. Accounting Review, 64(4), 710 .

[35] Noh, M., Park, H., \& Cho, M. (2017). The effect of the dependence on the work of other auditors on error in analysts' earnings forecasts. International Journal of Accounting and Information Management, 25(1), 110-136. doi:10.1108/IJAIM-11-20150077.

[36] Khatib, S. F. A., Abdullah, D. F., Elamer, A., Yahaya, I. S., \& Owusu, A. (2021). Global trends in board diversity research: a bibliometric view. Meditari Accountancy Research, ead of p, no. doi:10.1108/MEDAR-02-2021-1194.

[37] Khatib, S. F. A., Abdullah, D. F., Elamer, A. A., \& Abueid, R. (2021). Nudging toward diversity in the boardroom: A systematic literature review of board diversity of financial institutions. Business Strategy and the Environment, 30(2), 985-1002. doi:10.1002/bse.2665.

[38] Zamil, I. A., Ramakrishnan, S., Jamal, N. M., Hatif, M. A., \& Khatib, S. F. A. (2021). Drivers of corporate voluntary disclosure: a systematic review. Journal of Financial Reporting and Accounting, ead of p, no. doi:10.1108/JFRA-04-2021-0110.

[39] Glover, S. M., Jiambalvo, J., \& Kennedy, J. (2000). Analytical procedures and audit-planning decisions. Auditing, 19(2), 2645. doi:10.2308/aud.2000.19.2.27.

[40] Rose, A. M., Rose, J. M., Sanderson, K. A., \& Thibodeau, J. C. (2017). When should audit firms introduce analyses of big data into the audit process? Journal of Information Systems, 31(3), 81-99. doi:10.2308/isys-51837. 
[41] Bondarenko, S., Shlafman, N., Kuprina, N., Kalaman, O., Moravska, O., \& Tsurkan, N. (2021). Planning, Accounting and Control as Risk Management Tools for Small Business Investment Projects. Emerging Science Journal, 5(5), $650-666$. doi:10.28991/esj-2021-01302.

[42] Azhar, K., \& Setyaningrum, D. (2015). The effect of audit findings and the follow up of audit recomendation on corruption of ministries/institutions in Indonesia. In AAAA Annual Conference 2015, Bandung, Indonesia.

[43] Hazaea, S. A., Tabash, M. I., Zhu, J., Khatib, S. F. A., \& Farhan, N. H. S. (2021). "Internal audit and financial performance of Yemeni commercial banks: Empirical evidence.” Banks and Bank Systems, 16(2), 137-147. doi:10.21511/bbs.16(2).2021.13.

[44] Persellin, J. S., Schmidt, J. J., Vandervelde, S. D., \& Wilkins, M. S. (2019). Auditor perceptions of audit workloads, audit quality, and job satisfaction. Accounting Horizons, 33(4), 95-117. doi:10.2308/acch-52488.

[45] Heo, J. S., Kwon, S. Y., \& Tan, H. T. (2021). Auditors' Responses to Workload Imbalance and the Impact on Audit Quality. Contemporary Accounting Research, 38(1), 338-375. doi:10.1111/1911-3846.12612.

[46] Shaw, G. Deloitte. (2020). Potential implications of COVID-19 for the insurance sector. In Deloitte Insights (pp. 1-43). Available online: www2.deloitte.com/uk/en/insights/economy/covid-19/impact-of-covid-19-on-insurers.html (accessed on December 2021).

[47] Hoopes, J. L., Merkley, K. J., Pacelli, J., \& Schroeder, J. H. (2018). Audit personnel salaries and audit quality. Review of Accounting Studies, 23(3), 1096-1136. doi:10.1007/s11142-018-9458-y.

[48] Herazo, B., \& Lizarralde, G. (2016). Understanding stakeholders' approaches to sustainability in building projects. Sustainable Cities and Society, 26, 240-254. doi:10.1016/j.scs.2016.05.019.

[49] Alexeyeva, I., \& Svanström, T. (2015). The impact of the global financial crisis on audit and non-audit fees evidence from sweden. Managerial Auditing Journal, 30(4-5), 302-323. doi:10.1108/MAJ-04-2014-1025.

[50] Shahzad, K., Pouw, T., Rubbaniy, G., \& El-Temtamy, O. (2018). Audit quality during the global financial crisis: The investors' perspective. Research in International Business and Finance, 45, 94-105. doi:10.1016/j.ribaf.2017.07.137.

[51] Yeung, H. W. chung. (1995). Qualitative personal interviews in international business research: Some lessons from a study of Hong Kong Transnational Corporations. International Business Review, 4(3), 313-339. doi:10.1016/0969-5931(95)00012-O.

[52] Horton, J., Macve, R., \& Struyven, G. (2004). Qualitative Research: Experiences in Using Semi-Structured Interviews. The Real Life Guide to Accounting Research, 339-357. doi:10.1016/b978-008043972-3/50022-0.

[53] Ho, S. S. M., \& Wong, K. S. (2001). A study of corporate disclosure practice and effectiveness in Hong Kong. Journal of International Financial Management and Accounting, 12(1), 75-102. doi:10.1111/1467-646X.00067.

[54] Halbouni, S. S. (2015). The Role of Auditors in Preventing, Detecting, and Reporting Fraud: The Case of the United Arab Emirates (UAE). International Journal of Auditing, 19(2), 117-130. doi:10.1111/ijau.12040.

[55] Lois, P., Drogalas, G., Karagiorgos, A., \& Tsikalakis, K. (2020). Internal audits in the digital era: opportunities risks and challenges. EuroMed Journal of Business, 15(2), 205-217. doi:10.1108/EMJB-07-2019-0097.

[56] Fourati, Y. M. M., \& Bougacha, D. (2021). The Effect of the Mandatory IFRS Adoption on Audit Fees in Malaysia. In Corporate Governance and Its Implications on Accounting and Finance, IGI Global, 171-187. doi: 10.4018/978-1-7998-4852-3.ch008.

[57] Maher, M. W., Tiessen, P., Colson, R., \& Broman, A. J. (1992). Competition and audit fees. The Accounting Review, 67(1), 199-211.

[58] Krishnan, G. V., \& Zhang, Y. (2014). Is there a relation between audit fee cuts during the global financial crisis and banks' financial reporting quality? Journal of Accounting and Public Policy, 33(3), 279-300. doi:10.1016/j.jaccpubpol.2014.02.004.

[59] Xu, Y., Carson, E., Fargher, N., \& Jiang, L. (2013). Responses by Australian auditors to the global financial crisis. Accounting and Finance, 53(1), 301-338. doi:10.1111/j.1467-629X.2011.00459.x.

[60] PWC Network. (2020). Responding to the UK business impacts of coronavirus (COVID-19). PWC Network, March 2020, 1-6.

[61] Vieira, E. S. (2014). Corporate Risk in Family Businesses Under Economic Crisis. Innovar, 24(53), 61-74. doi:10.15446/innovar.v24n53.43909.

[62] Dalton, D. R., Hitt, M. A., Certo, S. T., \& Dalton, C. M. (2007). 1 The Fundamental Agency Problem and Its Mitigation. The Academy of Management Annals, 1(1), 1-64. doi:10.1080/078559806.

[63] Al-Okaily, J. (2020). The effect of family control on audit fees during financial crisis. Managerial Auditing Journal, 35(5), 645665. doi:10.1108/MAJ-12-2018-2114.

[64] DeFond, M. L. (1992). The Association Between Changes in Client Firm Agency Costs and Auditor Switching. Auditing: A Journal of Practice \& Theory, 11(1), 16-31.

[65] Hay, D., Shires, K., \& Van Dyk, D. (2020). Auditing in the time of COVID - the impact of COVID-19 on auditing in New Zealand and subsequent reforms. Pacific Accounting Review, 33(2), 179-188. doi:10.1108/PAR-09-2020-0155. 


\section{Appendix I}

\section{Questionnaire}

\section{Part (A) Demographic information}

Instruction: Tick as appropriate
(1) Age: $18-22$ 23-27 $28-32$ 33 and above
(2) Gender. Male Female
(3) What group of employees do you work for?
(a) Managers of audit offices
(b) Internal auditors

(c) External auditors

(d) Financial managers

(4) How many years have you done in this work?
(a) below 1
(b) below 3
(c) Below 5
(d) others

(5) Scientific qualification: Diploma

(b) Bachelor

(c) Master

other

\section{Part (B) SA- A- UN- D -SD}

\begin{tabular}{|c|c|c|c|c|c|c|}
\hline No & Statements & SA & A & $\mathbf{U N}$ & D & SD \\
\hline 1 & The COVID-19 negatively affected the liquidity of institutions, which led to demands to reduce audit fees & & & & & \\
\hline 2 & The COVID-19 didn't affect the selling and purchasing power of institutions & & & & & \\
\hline 3 & $\begin{array}{l}\text { The absence of enforcement of laws and standards regulating the relationship between institutions and auditors } \\
\text { greatly contributed to reducing audit fees during the COVID-19 period. }\end{array}$ & & & & & \\
\hline 4 & The large number of auditors resulting from layoffs from companies is one of the reasons for the low audit fees & & & & & \\
\hline 1 & The absence of modern systems and the reliance on social media only affected the confidence of the data obtained & & & & & \\
\hline 2 & $\begin{array}{l}\text { The use of analytical procedures to verify audit procedures gave the same result when performing traditional audit } \\
\text { procedures }\end{array}$ & & & & & \\
\hline 3 & The risk from the COVID-19 outbreak affected disorganization and anxiety among auditors & & & & & \\
\hline 4 & The time allocated to implementing audit procedures has increased during the outbreak of the COVID-19. & & & & & \\
\hline 5 & The COVID-19 has negatively affected the method of gathering and verifying audit evidence & & & & & \\
\hline 1 & The salaries provided to the auditors decreased during the COVID-19 outbreak & & & & & \\
\hline 2 & Auditors faced a challenge while requiring organizations to pay for work during risks & & & & & \\
\hline 3 & The auditors were asked to increase the time specified for auditing without material charge for the added time & & & & & \\
\hline 4 & $\begin{array}{l}\text { Due to the result of COVID-19 on the financial operations of the institutions, there was a delay in receiving the } \\
\text { salary }\end{array}$ & & & & & \\
\hline 5 & $\begin{array}{l}\text { The institutions stopped paying the rewards and incentives that were accustomed to them by the auditors, which } \\
\text { contributed to the failure to perform the audit well }\end{array}$ & & & & & \\
\hline 1 & COVID-19 epidemic has harmed the audit fees & & & & & \\
\hline 2 & COVID-19 epidemic has harmed the audit procedure's & & & & & \\
\hline 3 & COVID-19 epidemic has harmed the auditor's salaries & & & & & \\
\hline 4 & COVID-19 epidemic has harmed the audit control & & & & & \\
\hline 5 & COVID-19 epidemic has harmed the audit human capital & & & & & \\
\hline
\end{tabular}

Note: SA /strongly agreed (5), A /agreed (4), UN/undesired (3), SD /strongly disagreed (2), D/disagreed (1) 